\title{
Kesejahteraan Psikologis pada Ibu yang Memiliki Anak Tunagrahita Ditinjau dari Rasa Syukur dan Dukungan Sosial Suami
}

\author{
Fitri Febrina Asmarani, Inhastuti Sugiasih \\ Fakultas Psikologi Universitas Islam Sultan Agung \\ Email : inhastuti@unissula.ac.id
}

\begin{abstract}
Abstrak
Penelitian ini bertujuan untuk mengetahui keterkaitan kesejahteraan psikologis pada ibu yang memiliki anak tunagrahita ditinjau dari rasa syukur dan dukungan sosial suami. Penelitian ini menggunakan metode kuantitatif korelasional. Populasi dalam penelitian ini adalah ibu yang memiliki anak tunagrahita di SLB-C " $X$ " Semarang. Sampel penelitian ini berjumlah 120 ibu yang memiliki anak tunagrahita. Metode pengambilan sampel menggunakan quota sampling. Alat ukur yang digunakan dalam penelitian ini terdiri dari tiga skala. Skala kesejahteraan psikologis berisi 48 aitem memiliki koefisien reliabilitas $=0,882$, skala rasa syukur terdiri dari 28 aitem memiliki koefisien reliabilitas $=0,901$, serta skala dukungan sosial suami dengan 20 aitem memiliki koefisien reliabilitas $=0,953$ Analisis data menggunakan analisis regresi ganda. Hasil penelitian menunjukkan diperoleh $R=0,441$ dengan $F_{\text {hitung }} 10,522, p=0,000(p<0,05)$, yang berarti terdapat hubungan antara rasa syukur dan dukungan sosial suami terhadap kesejahteraan psikologis pada ibu yang memiliki anak tunagrahita. Untuk total koefisien determinasi sebesar 0,195 yang berarti bahwa sumbangan efektif dari rasa syukur dan dukungan sosial suami terhadap kesejahteraan psikologis pada ibu sebesar 19,5 \% sedangkan sisanya dipengaruhi oleh faktor lain.
\end{abstract}

Kata Kunci : Kesejahteraan Psikologis, Rasa Syukur, Dukungan sosial suami, tunagrahita

\section{Pendahuluan}

Kehadiran anak dalam keluarga merupakan suatu kebahagiaan dan dapat mempererat tali cinta antar suami-isteri. Hadirnya anak dalam keluarga dapat menjadi penerus generasi yang sangat di harapkan oleh keluarga tersebut. Setiap orang tua berharap agar memiliki anak dengan kondisi fisik maupun psikis yang sempurna. Pada kenyataannya tidak semua orang tua memiliki anak yang sempurna secara fisik maupun psikis, beberapa orang tua memiliki anak dengan keterbatasan baik secara fisik maupun psikis yang telah dialami sejak awal masa perkembangan. 
PSISULA: Prosiding Berkala Psikologi

Vol. 1, 2019

E-ISSN: 2715-002X

Abdullah (2013) memberikan istilah berkebutuhan khusus bagi anak yang dianggap mempunyai penyimpangan atau kelainan dari rata-rata perkembangan anak pada umumnya, dalam hal fisik, mental maupun karakteristik perilaku sosialnya. Anak berkebutuhan khusus ini meliputi anak-anak yang mengalami gangguan seperti, gangguan fisik (tunadaksa), emosional atau perilaku, pengelihatan (tunanetra), komunikasi, pendengaran (tunarungu), kesulitan belajar (tunalaras), atau mengalami retardasi mental (tunagrahita).

Hal selaras juga diungkapkan oleh (Somantri, 2006) salah satu yang termasuk dalam kategori anak berkebutuhan khusus adalah tunagrahita. Tunagrahita adalah istilah yang digunakan untuk menyebut anak yang memiliki kemampuan intelektual dibawah rata-rata, ditandai dengan adanya keterbatasan intelegensi dan ketidakmampuan dalam berinteraksi sosial. Tunagrahita atau biasa disebut dengan retardasi mental dengan karakteristik umum yaitu adanya keterbatasan intelektual, keterbatasan sosial dan fungsi-fungsi mental lainnya (Somantri, 2006). Somantri (2006) juga menambahkan bahwa anak tunagrahita kurang mampu untuk mempertimbangkan sesuatu, membedakan antara yang baik dan buruk, karena kemampuan intelektual yang terbatas sehingga anak tunagrahita tidak dapat membayangkan terlebih dahulu konsekuensi yang di dapat dari suatu perbuatan. Praptiningrum (2007) menjelaskan beberapa faktor penyebab tunagrahita yaitu faktor genetis atau keturunan, faktor metabolisme dan gizi buruk, infeksi keracunan yang biasa terjadi saat kehamilan, proses kelahiran, dan lingkungan buruk.

Eliyanto \& Hendriani (2013) Data Badan Pusat Statistik (BPS) 2009 menunjukkan bahwa lebih dari 6 juta penduduk Indonesia menyandang kebutuhan khusus. Berturut-turut yaitu 1,7 juta (tunanetra); 1,6 juta (tunadaksa); 1,2 juta penyakit kronis; 779 ribu (tunagrahita); dan 603 ribu (tunanetra/tunarungu). Zakarya, dkk (2016) menyatakan bahwa jumlah anak tunagrahita di indonesia diperkirakan sebesar 3\%. angka ini diperkuat dengan data dari Badan pusat Statistik (BPS) 2016 yang menunjukkan di Indonesia terdapat 1.750.000-5.250.000 anak dengan tunagrahita. 
PSISULA: Prosiding Berkala Psikologi

Vol. 1, 2019

E-ISSN: 2715-002X

American Asociation on Mental Deficiency (AAMD) (Gabe, 2008) mendefinisikan tunagrahita sebagai kelainan yang meliputi fungsi intelektual umum dibawah rata-rata, yaitu IQ 84 ke bawah berdasarkan tes yang telah dilakukan. Klasifikasi yang digunakan di Indonesia sesuai dengan peraturan perundangundangan (PP) 72 tahun 1991 adalah tunagrahita ringan dengan IQ 50-70, tunagrahita sedang dengan IQ 30-50, tunagrahita berat dan sangat berat IQ kurang dari 30 .

Melati \& Levianti (2013) menjabarkan bahwa orangtua merupakan sumber kelekatan bagi anak dan merupakan figur lekat bagi kehidupan anak. Orang tua harus memberikan dukungan yang penuh untuk anak secara terus-menerus untuk menjalani kehidupannya. Orangtua juga berperan sebagai advocates bagi kepentingan anak, sebagai guru di rumah dan sebagai pengasuh. Orangtua harus membantu anak dalam mengembangkan kemampuan pada berbagai aspek kehidupan, seperti kemampuan komunikasi, mobilitas, perkembangan panca indra, motorik halus dan kasar, kognitif dan sosial. Supaya orangtua atau ibu mampu mengoptimalkan perkembangan anak, maka mereka harus memiliki kesejahteraan psikologis yang baik.

Kesejahteran psikologis adalah keadaan seseorang yang bebas dari tekanan mental, memiliki pandangan yang positif mengenai kehidupannya, memiliki tujuan hidup, berhubungan yang baik dengan orang lain, mampu mengatur tindakannya sesuai dengan tujuan hidupnya (Ryff, 1989). Menurut Hamburger (Sari, 2015) individu yang memiliki kesejahteraan psikologis tinggi merasa mampu dalam menjalani hidup, mendapatkan dukungan, puas dengan kehidupan dan mempunyai perasaan yang bahagia.

Menurut Papalia (20..) individu dengan kesejahteraan psikologis yang baik adalah individu yang mampu merealisasikan kemampuan dirinya secara berkelanjutan, mampu membentuk hubungan baik dengan orang lain, mampu mandiri dalam menyelesaikan tekanan yang dihadapi, menerima diri sendiri dengan baik, memiliki arti dalam hidup, dan mampu mengontrol lingkungan eksternalnya. Hal yang serupa diungkapkan oleh (Ryff \& Keyes, 1995) bahwa kesejahteraan 
PSISULA: Prosiding Berkala Psikologi

Vol. 1, 2019

E-ISSN: 2715-002X

psikologis adalah kemampuan individu dalam menerima kondisinya dengan apa adanya, dapat membentuk hubungan yang harmonis dengan orang lain, mampu hidup mandiri terhadap tekanan sosial, mampu mengontrol lingkungan luar, memiliki makna dalam hidup serta mampu mewujudkan kemampuan dirinya secara berkelanjutan.

Pada kenyataannya tidak semua orangtua memiliki kesejahteraan psikologis yang baik. Ketika orangtua mengetahui bahwa mereka memiliki anak berkebutuhan khusus, harapan mereka selama ini seketika berubah menjadi kekecewaan. Hasil penelitian yang dilakukan (Kumar, 2008) menyatakan orang tua yang memiliki anak dengan tunagrahita dipastikan lebih mengalami stres psikologis dibanding dengan orang tua yang memiliki anak normal. Stres tersebut diakibatkan karena orang tua memiliki beban tersendiri baik secara fisik, psikis dan sosialnya. Hal ini lebih dapat dirasakan oleh ibu yang pada umumnya lebih banyak berhubungan dengan anak. Kondisi seperti ini akan mempengaruhi kesejahteraan psikologi orangtua terutama ibu.

Hal tersebut dibuktikan dari hasil wawancara yang dilakukan oleh peneliti bahwa setiap ibu yang memiliki anak tunagrahita akan mengalami kesedihan, kekecewaan dan kemarahan. Bahkan ada yang merasa mengalami kebingungan dalam mengasuh sang anak. Hal tersebut yang nantinya dapat mempengaruhi kesejahteraan psikologis ibu. Menurut (Wood, Joseph, \& Maltby, 2009) banyak faktor yang dapat mempengaruhi kesejahteraan psikologis individu, diantaranya adalah jenis kelamin, usia, kepribadian, kecerdasan emosi, budaya, status sosial ekonomi dan rasa syukur. Penelitian yang dilakukan (Wood, Joseph, \& Maltby, 2009) menunjukkan bahwa rasa syukur memiliki hubungan yang positif dengan aspek kesejahteraan psikologis.

Emmons (2003) menyatakan bersyukur berkaitan penting dengan pengkondisian positif pada diri seseorang, yang dipersepsikan dapat meningkatkan kesejahteraan psikologis individu. Oleh karena itu bersyukur merupakan kondisi psikologis yang dapat menunjukkan afeksi yang sesaat hingga jangka panjang yang berfungsi sebagai penyeimbang hidup bagi individu. 
PSISULA: Prosiding Berkala Psikologi

Vol. 1, 2019

E-ISSN: 2715-002X

Menurut Watkins, dkk (2003) individu yang memiliki rasa syukur dapat mengindikasikan sejauhmana individu tersebut merasa bahagia dilihat dari sejauhmana mereka bersyukur terhadap hidupnya. (Peterson\& Seligman, 2004) juga menyatakan bahwa rasa syukur adalah ungkapan terimakasih dari individu yang mendapat respon baik dari pemberian orang lain, baik pemberian itu berupa nyata atau kedamaian bagi individu tersebut.

Emmons \& Tsang (2002) berpendapat bahwa individu yang bersyukur tidak hanya menunjukkan sikap positif seperti tekun dalam menjalani hidup, antusias dan penuh perhatian, tetapi juga lebih murah hati, empati terhadap orang lain dan bersedia membantu orang lain. Froh (2010) menyatakan bahwa dengan bersyukur dapat menjadikan individu merasa lebih sejahtera, optimis dan merasakan kepuasan dalam hidupnya.

Faktor lain yang dapat mempengaruhi kesejahteraan psikologis individu selain rasa syukur adalah dukungan sosial. Taylor (Amawidyati\& Utami, 2015) ada beberapa sumber dukungan sosial, dukungan sosial bisa di dapatkan dari pasangan, orangtua, teman dan lingkungan sekitar. Pada penelitian ini, dukungan yang digunakan adalah dukungan sosial suami. Dukungan sosial suami sangat diperlukan bagi istri karena suami adalah orang terdekat yang mampu memberikan dukungan dalam jangka waktu panjang.

Sarason (Kumalasari \& Ahyani, 2012) menjelaskan dukungan sosial merupakan kesediaan, keberadaan dan kepedulian dari individu lain yang dapat diandalkan, serta seseorang yang menyanyangi dan menghargai kita. Dukungan sosial sangat dibutuhkan bagi ibu yang memiliki anak tunagrahita. Dimana dukungan sosial merupakan faktor penting bagi ibu dalam mengasuh anak tunagrahita.

Lestari (Pradana \& Kustanti, 2017) dukungan yang diberikan suami kepada istri akan membuat istri semakin merasa diterima dengan kondisi yang sedang dialaminya. Menurut Uchino (Sarafino, 2002) dukungan sosial mengacu pada kenyamanan, perhatian, penghargaan, atau ketersediaan bantuan kepada seseorang dari orang lain atau suatu kelompok. Dukungan sosial dapat berasal dari seseorang (professional maupun tidak) yang mampu mengatasi permasalahan 
PSISULA: Prosiding Berkala Psikologi

Vol. 1, 2019

E-ISSN: 2715-002X

individu yang mengalami distress (Pradana \& Kustanti, 2017). Berdasarkan paparan diatas maka peneliti tertarik untuk menguji kaitan antara rasa syukur dan dukungan sosial suami dengan kesejahteraan psikologi pada ibu yang memiliki anak tuna grahita.

\section{Metode Penelitian}

Metode yang digunakan dalam penelitian ini adalah kuantitaf korelasional yang melibatkan dua variable bebas dan satu variable tergantung. Variabel bebas dalam penelitian ini adalah rasa syukur dan dukugan sosial suami, sedangkan variable terikatnya adalah kesejahteraan psikologis. Populasi dalam penelitian ini adalah 120 ibu yang memiliki anak tuna grahita bersekolah di SLB X di kota Semarang, dengan teknik pengambilan sampel menggunakan quota sampling. Metode pengumpulan data dalam penelitian ini menggunakan 3 skala yaitu, skala rasa syukur, skala dukungan sosial suami dan skala kesejahteraan psikologis. Skala kesejahteraan psikologis terdiri 38 aitem dengan reliabilitas $\alpha=0,882$. Skala rasa syukur terdiri dari 25 aitem dengan reliabilitas $\alpha=0,901$. Skala dukungan sosial suami terdiri dari 20 aitem dengan reliabilitas $\alpha=0,953$.

\section{Hasil}

Sebelum menguji hipotesis penulis melakukan uji asumsi. Uji normalitas dilakukan dengan tujuan untuk melihat normal dan tidaknya distribusi data variabel penelitian. Berdasarkan hasil uji normalitas pada variabel kesejahteraan psikologis nilai KS-Z $=0,692$ dengan $p=0,724(p>0.05)$ artinya berdistribusi normal. Rasa syukur memiliki nilai KS-Z $=1,219$ dengan $p=0,102(p>0,05)$ artinya berdistribusi normal. Dukungan sosial suami memiliki KS-Z $=1,508$ dengan $p=0,021 \quad(p<0,05)$ artinya berdistribusi tidak normal.

Berdasarkan hasil uji lineritas antara variabel kesejahteraan psikologis dengan rasa syukur diperoleh hasil $F=17,924, p=0,000(p<0,01)$. Variabel kesejahteraan psikologis dengan dukungan sosial suami diperoleh hasil $F=3,898, p=0,051$ $(p<0,01)$. Artinya kedua variabel tersebut memiliki hubungan linier atau persamaan 
PSISULA: Prosiding Berkala Psikologi

Vol. 1, 2019

E-ISSN: 2715-002X

variabel membentuk garis lurus. Selanjutnya dilakukan uji multikolinearitas bertujuan untuk menguji adanya korelasi antar variabel bebas dalam model regresi. Berdasarkan hasil analisis diketahui bahwa nilai tolerance sebesar 0,988 dengan nilai Variance Inflation Factor (VIF) pada kedua variabel sebesar 1,012 artinya nilai tersebut lebih kecil dari 10, sehingga hasil multikolinearitas menunjukkan bahwa tidak terjadi multikolinearitas pada variabel bebas dalam penelitian ini.

Berdasarkan hasil uji hipotesis mengunakan teknik regresi dua predictor dihasilkan korelasi $R_{y(1,2} 0,441$ dan $F_{\text {hitung }}=10,522$ dengan $p=0,000(p<0,05)$. Hal ini menunjukkan adanya hubungan yang signifikan antara rasa syukur dan dukungan sosial suami terhadap kesejahteraan psikologis. Nilai koefisien prediktor rasa syukur sebesar 0,524 dengan koefisien dukungan sosial suami sebesar 0,183 dengan nilai konstan sebesar 68,688. Persamaan garis regresi diperoleh $Y=0,524 X 1+0,183 \times 2+$ 68,688 .

Besarnya koefisien determinasi sebesar 0,195 yang berarti bahwa sumbangan efektif dari variabel rasa syukur dan dukungan sosial suami terhadap kesejahteraan psikologis pada ibu sebesar 19,5 \% sedangkan sisanya dipengaruhi oleh faktor lain.

\section{Pembahasan}

Tujuan dilakukannya penelitian ini adalah untuk menguji apakah terdapat adanya hubungan antara rasa syukur dan dukungan sosial suami terhadap kesejahteraan psikologis pada ibu yang memiliki anak tunagrahita di SLB-C " $X$ " Semarang. Berdasarkan analisa yang telah dilakukan pada hipotesis pertama diperoleh skor R12y $=0,441$ dan $F_{\text {hitung }}=10,522, p=0,000(p<0,05)$. Hal ini menunjukkan adanya hubungan yang signifikan antara rasa syukur dan dukungan sosial suami terhadap kesejahteraan psikologis pada ibu yang memiliki anak dengan tunagrahita di SLB-C "X" Semarang. Terdapat nilai koefisien prediktor rasa syukur sebesar 0,524 dengan koefisien dukungan sosial suami sebesar 0,183. Untuk total koefisien determinasi sebesar 0,195 yang berarti bahwa sumbangan efektif dari 
PSISULA: Prosiding Berkala Psikologi

Vol. 1, 2019

E-ISSN: 2715-002X

variabel rasa syukur dan dukungan sosial suami terhadap kesejahteraan psikologis pada ibu sebesar $19,5 \%$ sedangkan sisanya dipengaruhi oleh faktor lain.

Kartikasari (2013) menyatakan terdapat beberapa faktor yang dapat mempengaruhi kesejahteraan psikologis individu, yaitu usia, jenis kelamin, status sosial ekonomi, faktor dukungan sosial, kepribadian dan religiusitas. Religiusitas merupakan salah satu yang dapat mempengaruhi kesejahteraan psikologis individu. Menurut penelitian (McCullough, Michael E., 2002) bahwa religiusitas berpengaruh terhadap rasa syukur dari individu, karena religiusitas menyadarkan setiap indvidu bahwa kehidupan yang terjadi dalam hidupnya merupakan suatu hal yang telah dikaruniakan Tuhan kepadanya.

Hasil uji korelasi parsial untuk menguji hubungan antara rasa syukur dengan kesejahteraan psikologis pada ibu yang memiliki anak tunagrahita dengan mengontrol variabel dukungan sosial suami didapatkan hasil terdapat hubungan positif yang signifikan. Artinya semakin tinggi rasa syukur maka semakin baik pula kesejahteraan psikologis, sebaliknya semakin rendah rasa syukur maka semakin buruk kesejahteraan psikologis. Menurut (Peterson \&Seligman, 2004) salah satu kekuatan diri yang positif akan memberikan keuntungan bagi diri individu adalah rasa syukur. Adanya rasa syukur mampu membantu individu dalam meningkatkan pertumbuhan pribadi. Seseorang dengan kesejahteraan psikologis yang tinggi memiliki perasaan bahwa diri itu tumbuh dan berkembang, terbuka untuk hal baru, menyadari kemampuan diri, serta melakukan perbaikan dalam diri dari waktu ke waktu. Hal ini juga didukung oleh penelitian dari (Wood, Joseph, \& Maltby, 2009) bahwa rasa syukur menjadi hal yang penting bagi kesejahteraan psikologis individu. Hasil penelitian dari (Fitri, 2012) menunjukkan adanya hubungan positif yang signifikan antara rasa syukur dan kesejahteraan psikologis pada mahasiswa Universitas Indonesia. Hasil uji korelasi sebesar 0,536. Rasa syukur memiliki sumbangan efektif sebesar 0,2873 (28,73\%) terhadap kesejahteraan psikologis. Hal yang sama dibuktikan hasil penelitian dari (Akbar, 2018) rasa syukur dan kesejahteraan psikologis memiliki hubungan positif yang signifikan. Hasil uji korelasi sebesar 0,635. Rasa syukur memiliki sumbangan efektif sebesar 0,403 (40,3\%) 
PSISULA: Prosiding Berkala Psikologi

Vol. 1, 2019

E-ISSN: 2715-002X

terhadap kesejahteraan psikologis. Hal tersebut mengartikan bahwa adanya rasa syukur berpengaruh terhadap kesejahteraan psikologis yang dirasakan individu.

Uji korelasi parsial untuk menguji hubungan antara dukungan sosial suami dengan kesejahteraan psikologis ibu yang memiliki anak tunagrahita dengan mengontrol rasa syukur diketahui terdapat hubungan yang positif signifikan. Hal ini menunjukkan bahwa semakin baik dukungan sosial suami maka semakin baik kesejahteraan psikologisnya dan sebaliknya semakin buruk dukungan sosial suami maka semakin buruk kesejahteraan psikologisnya. Nopiando (2012) menjelaskan bahwa seseorang dengan tingkat kesejahteraan psikologis yang tinggi akan memiliki kepuasan dalam hidup dan lebih sedikit mengalami emosi negatif. Tylor (Pradana \& Kustanti, 2017) dukungan sosial dari suami merupakan salah satu bentuk dukungan sosial dari keluarga karena suami merupakan orang yang keberadaannya saat dibutuhkan dalam keluarga. Bentuk dukungan yang diberikan suami pada isteri dapat berupa bantuan informasi, emosional dan bantuan secara langsung.

Penelitian dari (Pradana \& Kustanti, 2005) mengatakan bahwa terdapat hubungan yang positif dan signifikan antara dukungan sosial suami dengan psychological well-being pada ibu yang memiliki anak autisme. Hasil uji korelasi sebesar 0,485. Dukungan sosial suami memberikan sumbangan efektif sebesar $23,6 \%$ terhadap psychological well-being pada ibu yang memiliki anak autisme.

\section{Kesimpulan}

Hasil penelitian menunjukkan bahwa rasa syukur dan dukungan suami memiliki peranan dalam kesejahteraan psikologis pada lbu yang memiliki anak tunagrahita. Ada hubungan yang signifikan antara rasa syukur dengan kesejahteraan psikologi dengan mengontrol variabel dukungan suami, disamping itu juga terdapat hubungan yang signifikan antara dukungan suami dengan kesejahteraan psikologis dengan mengontrol rasa syukur. Sehingga dapat dikatakan ibu yang memiliki rasa syukur dan dukungan suami akan mempunyai kesejahteraan psikologis yang baik. 


\section{Daftar Pustaka}

Abdullah, N. (2013). Mengenal anak berkebutuhan khusus. Jurnal Pendidikan Khusus.2 (1), 65-78.

Akbar, R. m. (2018). Hubungan kebersyukuran dengan psychological well-being pada pasien yang mengidap penyakit diabetes mellitus tipe 2.Skripsi: Universitas Islam Indonesia, Fakultas Psikologi

Amalia, M., \& Indiati, A. (2005). Hubungan antara dukungan sosial dengan kesejahteraan psikologis pada ibu yang memiliki anak retradasi mental. Jurnal Psikologi UII, 1 (3), 110-116.

Amawidyati, S. A., \& Utami, M. S. (2015). Religiusitas dan psychological well-being pada korban gempa. Jurnal Psikologi, 34 (2), 164-176.

Azani. (2012). Gambaran psychological well-being. Jurnal Emphaty, 1 (1). 26-35

Azwar, S. (2012). Metode penelitian. Yogyakarta: Pustaka Pelajar.

Azwar, S. (2012). Penyusunan skala psikologi. Yogyakarta: Pustaka Belajar.

Baron, R. A., \& Byrne, D. (2005). Psikologi sosial, jilid 2 (edisi 10). Jakarta: Erlangga.

Dagun, S. M. (2002). Psikologi keluarga. Jakarta: Rineka Cipta.

Debby, C. (2016). Hubungan antara gratittude dengan psychological well-being pada mahasiswa UKSW yang kuliah sambil bekerja full time. Jurnal Psikologi, 13 (1). 46-64

Desiningrum, D. R. (2014). Kesejahteraan psikologis lansia janda/duda ditinjau dari persepsi terhadap dukungan sosial dan gender. Jurnal Psikologi Undip, 13 (2), 102-106.

Elfanany, B. (2013). Rahasia dahsyat di balik keajaiban sabar, syukur \& sholat. Yogyakarta: Pinang Merah Publiser.

Eliyanto, H., \&Hendriani, W. (2013). Hubungan kecerdasan emosi dengan penerimaan diri terhadap anak kandung yang mengalami cerebral palsy. Jurnal Psikologi Pendidikan dan Perkembangan, 2 (2), 22-60

Emmons, R. A. (2003). Counting blessings versus burdens: An experimental investigation of gratitude and subjuctive well-being in daily life. Journal of Personality and Social Psychology, 84 (2), 377-389. 
PSISULA: Prosiding Berkala Psikologi

Vol. 1, 2019

E-ISSN: 2715-002X

Emmons, R. A., \& Stern, R. (2013). Gratitude as a psychotherapeutic intervention. Journal of clinical psychology, 69 (8), 846-855.

Emmons, R. A., \& Tsang, J.-A. (2002). The grateful disposition : A conceptual and empirical topography. Journal of personality and social psychology, 82 (1), 112-127.

Fitria, P, O. (2012). Hubungan antara gratittude dan psychological well-being pada mahasiswa. Skripsi : Universitas Indonesia, Fakultas Psikologi.

Froh, J. J. (2010). Gratittude and the reduced costs of materialism in adolescents. Journal Happiness Study.20 (9), 116-127

Gabe, R. T. (2008). Anak Tunagrahita. Jurnal Gejala Arsitektur Sekolah, 3 (2), 6-12.

Hardjo, S., \& Novita, E. (2015). Hubungan dukungan sosial dengan psychological well-being pada remaja korban sexual abuse. Jurnal Psikologi. 3 (2), 2260 .

Harimukthi, M. T., \& Dewi, K. S. (2014). Eksplorasi kesejahteraan psikologis individu dewasa awal penyandang tunanetra. Jurnal psikologi undip, 13 (1), 64-77.

Huppert, F. A. (2009). Psychological well-being : Evidence regarding its causes and consequences. Journal compiliation .

Hurlock, E. B. (1999). Psikologi perkembangan. Jakarta: Erlangga.

Kartikasari, N. Y. (2013). Body dissatisfaction terhadap psychological well-being pada Karyawati. Jurnal IImiah Psikologi Terapan, 1 (2), 13-25.

Keyes, C. L., Shmotkin, D., \& Ryff, D. C. (2007). Optimizing Well-Being: The Empirical Encounter of Two Traditions. Jurnal Of Personality and Social Psychology, $82(6), 1007-1022$.

Kumalasari, F., \& Ahyani, L. (2012). Hubungan anatara dukungan sosial dengan penyesuaian diri remaja di panti asuhan. Jurnal Psikologi Pitutur, 1 (2), 2635 .

Kumar, G. V. (2008). Psychologycal stress and coping strategies of the parents of mentally challenged children. Journal of The Indian Academy Of Applied Psychology, 34 (2), 227-231.

Listiyandini, R. A. (2015). Mengukur rasa syukur: Pengembangan model awal skala bersyukur versi indonesia. Jurnal psikologi ulayat, 2 (2), 473-496.

McCullough, M. E., \& Emmons, R. A. (2002). The Greateful Disposition: A Conceptual and Empirical Topography. Jurnal of Personality and Social Psychology, 82 (1), 112-127. 
PSISULA: Prosiding Berkala Psikologi

Vol. 1, 2019

E-ISSN: 2715-002X

McCullough, Michael E. (2002). The grateful disposition : A conceptual and empirical topography. Journal Of Personality and social Psychology.

Melati, \& Levianti. (2013). Penerimaan diri ibu yang memiliki anak tunanetra. Jurnal Psikologi, 11 (1). 16-27

Nopiando, B. (2012). Hubungan antara job insecurity dengan kesejahteraan psikologis pada karyawan outsourcing. Journal of Social And Industrial Psychology, 1 (2). 30-45

Peterson, C., \& Seligman, M. E. (2004). Strengths of character and well-being. Journal Of Social and Clinical Psychology, 23 (5), 603-619.

Philip C. Watkins. (2003). Gratuttude and happiness: development of a measure of gratittude, and relationships with subjective well-being. Journal Social Behavior and Personality, 31 (5), 431-452.

Pradana, A. P., \& Kustanti, E. R. (2017). Hubungan antara dukungan sosial suami dengan psychologycal well-being pada ibu yang memiliki anak autisme. Jurnal Empati, 6 (2), 83-90.

Praptiningrum, N. (2007). Perilaku adaptif anak tunagrahita dewasa. Jurnal Pendidikan Khusus, 3 (1), 1-10.

Priyanto, D. (2016). Belajar alat analisis data dan cara pengolahannya dengan SPSS. Yogyakarta: Gava Media.

Ramadhani, T. (2016). Kesejahteraan psikologi (psychological well-being) siswa yang orangtuanya bercerai. Jurnal Bimbingan dan Konseling, 5 (1), 11-20.

Ratnayanti, Theresia Lisiau; Wahyuningrum, Enjang. (2016). Hubungan antara gratitude dengan psychological well-being ibu yang memiliki anak tunagrahita di slb negri salatiga.Satya Widya, 32 (2), 57-64.

Rochma, I. (2016) Hubungan antara kebersyukuran dengan makna hidup pada pensiunan. Skripsi : Universitas Islam Indonesia, Fakultas Psikologi dan Ilmu Sosial Budaya.

Ryan, R. M., \& Deci, E. L. (2001). On happiness and human potentials a review of research on hedonic and eudaimonic well-being. Journal Psychology (52), 141-66.

Ryff, C. D. (1989). Happiness is everything, or is it ? explorations on the meaning of psychological well-being. Journal Of Personality and Social Psychology, 57 (6), 1068-1081. 
PSISULA: Prosiding Berkala Psikologi

Vol. 1, 2019

E-ISSN: 2715-002X

Ryff, C. D., \& Keyes, C. L. (1995). The structure of psychological well-being revisited. Journal Of Personality and Social Psychology, 69 (4), 719-727.

Santrock, J. W. (2006). Adolescence (Perkembangan Remaja) (Terjemahan). Jakarta: Erlangga.

Sarafino, E. P. (2002). Health psychology, biopsychosocial interactions (Ed 4). United States: John Wilet \& Sons Inc.

Sari, N. A. (2015). Psychological well-being pada kepala keluarga yang mengalami pemutusan hubungan kerja oleh perusahaan batu bara di desa bukit pariaman. eJournal Psikologi, 4 (1), 1-12.

Sholiha, R., Bintari, D. R., \& Nurwianti, F. (2015). Hubungan trait dan psychological well-being pada masyarakat kota jakarta. Psychology Forum UMM, 3 (2), 28-36.

Smet, B. (1994). Psikologi kesehatan. Jakarta: Grasindo.

Somantri, T. S. (2006). Psikologi anak luar biasa. Bandung: Refika Aditama.

Sugiyono. (2017). Metode penelitian kuantitatif, kualitatif dan R\&D. Bandung: Alfabeta.

Sugiyono. (2014). Statistika untuk penelitian. Bandung: Alfabeta.

Sujana, R. C., Wahyuningsih, H., \& Uyun, Q. (2015). Peningkatan kesejahteraan psikologis pada penderita diabetes militus tipe 2 dengan menggunakan group positive psychotherapy. Jurnal Intervensi Psikologi, 7 (2), 214-227.

Suryabrata, S. (2003). Metodologi penelitian. Jakarta: Rajawali.

Ulfasari, R. (2018). Hubungan antara kebersyukuran dan psychological well-being pada ibu yang memiliki anak berkebutuhan khusus.Skripsi : Universitas Islam Indonesia, Fakultas Psikologi dan Ilmu Sosial Budaya.

Vania, I. W. (2014). Hubungan antara dukungan sosial dengan psychological wellbeing caregiver penderita gangguan skizofrenia. Jurnal Empati, 3 (4), 8999.

Watkins, P. C., Woodward, K., Stone, T., \& Kolts, R. L. (2003). Gratitude and happines: Development of a measure of gratitude, and relationships with subjective well-being. Journal Of Behavioral and Personality, 31 (5), 431452.

Wood, A. M., Froh, J. J., \& Geraghty, A. W. (2010). Gratitude and well-being: A review and theoretical integration. Clinical Psychology Review , 890-905. 
PSISULA: Prosiding Berkala Psikologi

Vol. 1, 2019

E-ISSN: 2715-002X

Wood, A. M., Joseph, S., \& Maltby, J. (2009). Gratittude predicts psychological wellbeing above the big five facets. Journal Personality and Individual Differences, 443-447.

Zakarya, Y. N., Dewi, E. I., \& Susanto, T. (2016). Pengaruh pelatihan cuci tangan bersih dengan metode bermain puzzle terhadap kemampuan melakukan cuci tangan anak tunagrahita di SDLB-C TPA kabupaten Jember. e-Jurnal Pustaka Kesehatan, 4 (3), 31-38. 